\title{
Bacillus cereus-induced food-borne outbreaks in France, 2007 to 2014: epidemiology and genetic characterisation
}

\author{
B Glasset ${ }^{12}$, S Herbin ${ }^{14}$, L Guillier ${ }^{1}$, S Cadel-Six 1 , M Vignaud 1 , J Grout ${ }^{1}$, S Pairaud 1 , V Michel ${ }^{3}$, J Hennekinne ${ }^{1}$, N Ramarao ${ }^{2}$ \\ 4 , A Brisabois ${ }^{14}$ \\ 1. Université Paris-Est, ANSES, Laboratory for Food Safety, Maisons-Alfort Cedex, France \\ 2. Micalis Institute, INRA, AgroParisTech, Université Paris-Saclay, Jouy-en-Josas, France \\ 3. ACTALIA, La Roche sur Foron, France \\ 4. These authors contributed equally to this work
}

Correspondence: Anne Brisabois (anne.brisabois@anses.fr)

Citation style for this article:

Glasset B, Herbin S, Guillier L, Cadel-Six S, Vignaud M, Grout J, Pairaud S, Michel V, Hennekinne J, Ramarao N, Brisabois A. Bacillus cereus-induced food-borne outbreaks in France, 2007 to 2014: epidemiology and genetic characterisation. Euro Surveill. 2016;21(48):pii=30413. D0I: http://dx.doi.org/10.2807/1560-7917. ES.2016.21.48.30413

Article submitted on 22 December 2015 / accepted on 16 July 2016 / published on 01 December 2016

The aim of this study was to identify and characterise Bacillus cereus from a unique national collection of 564 strains associated with 140 strong-evidence food-borne outbreaks (FBOs) occurring in France during 2007 to 2014. Starchy food and vegetables were the most frequent food vehicles identified; 747 of 911 human cases occurred in institutional catering contexts. Incubation period was significantly shorter for emetic strains compared with diarrhoeal strains A sub-panel of 149 strains strictly associated to 74 FBOs and selected on Coliphage M13-PCR pattern, was studied for detection of the genes encoding cereulide, diarrhoeic toxins (Nhe, Hbl, CytK1 and CytK2) and haemolysin (Hlyll), as well as panC phylogenetic classification. This clustered the strains into 12 genetic signatures (GSs) highlighting the virulence potential of each strain. GS1 (nhe genes only) and GS2 (nhe, $h b l$ and cytK2), were the most prevalent GS and may have a large impact on human health as they were present in $28 \%$ and $31 \%$ of $\mathrm{FBO}$, respectively. Our study provides a convenient molecular scheme for characterisation of $B$. cereus strains responsible for FBOs in order to improve the monitoring and investigation of $B$. cereus-induced FBOs, assess emerging clusters and diversity of strains.

\section{Introduction}

The Bacillus cereus sensu lato group includes the following closely related spore-forming species: $B$. cereus sensu stricto, $B$. thuringiensis, $B$. cytotoxicus, $B$. weihenstephanensis, $B$. mycoides, $B$. pseudomycoides and $B$. anthracis [1]. The first four species are known to be involved in food poisoning [1]. B. thuringiensis is also mainly known as a biopesticide due to production of insecticidal toxins [2]. B. anthracis is highly virulent in mammals and is the causative agent of anthrax [3]. $B$. cytotoxicus is a newly identified group of strains that induce severe food poisoning. They are characterised by the production of cytotoxin K-1 (CytK-1) and a relatively high genomic diversity compared with other $B$. cereus strains [1].

$B$. cereus is currently the second most frequently found causative agent of confirmed and suspected foodborne outbreaks (FBOs) in France after Staphylococcus aureus [4]. Depending on the evidence implicating a food vehicle source during epidemiological and microbiological FBO investigations, the outbreaks are referred as a strong-evidence or weak-evidence FBO. Briefly, an FBO is defined as 'strong-evidence' when the following information is known and reported: food vehicle, food source, the link between outbreak cases and the food vehicle, place of exposure, and contributory factors. When several parts of the information are missing, the FBO is considered as 'weak-evidence' FBO [5].

Between 2006 and 2014 in France, B. cereus was recorded as the second or third major cause in weakevidence FBOs. In 2014, B. cereus represented the second cause in weak-evidence FBOs, with 1,902 human cases for $224 \mathrm{FBOs}$, and the second cause of strong-evidence FBOs, with 23 FBOs accounting for 447 human cases and 18 hospitalisations [4]. The increase in $B$. cereus-induced FBOs is partly due to the input of national health and food safety authorities in the epidemiological and microbiological investigations of suspected FBOs. Indeed, $B$. cereus strains isolated from foodstuff suspected of being involved in an FBO are now usually collected by the laboratory for food safety in ANSES. To illustrate this, during 1996 to 2005, only 94 strong-evidence and 196 weak-evidence FBOs were reported, whereas for 2014 alone, 23 and 241 strongand weak-evidence FBOs were notified, respectively showing the high input of the authorities. Nevertheless, the number of total human $B$. cereus cases is likely to 


\section{FIGURE 1}

Distribution of food-borne outbreaks associated to Bacillus cereus by month of outbreak compared to a theoretical uniform distribution, France, 2007-2014

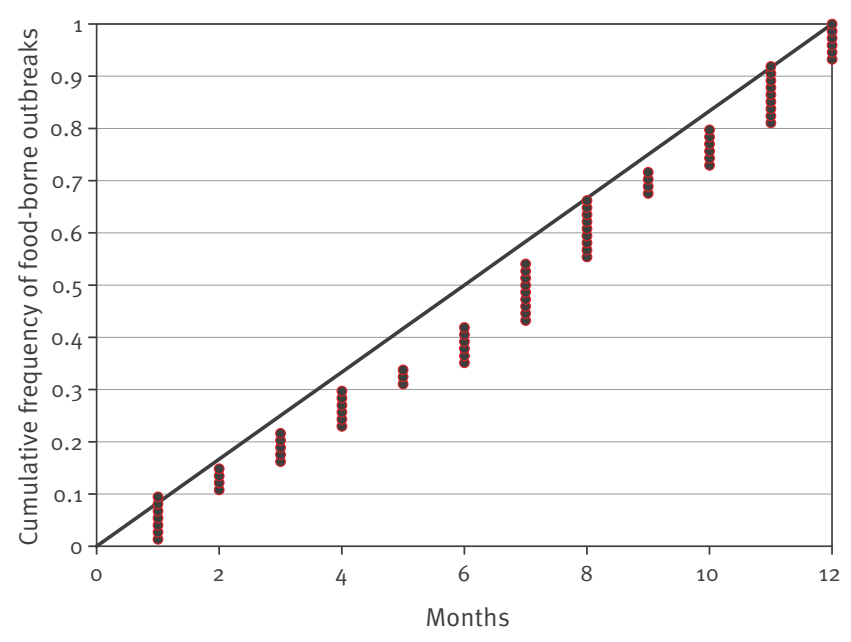

For the theoretical uniform distribution, each dot represents a food-borne outbreak.

be underestimated because individuals with gastrointestinal infections rarely seek medical advice and if they do, stools sample are not always asked for by physicians.

$B$. cereus can induce two types of gastrointestinal disease, leading to emetic or diarrhoeal syndromes. The symptoms associated with $B$. cereus infection are generally mild and self-limiting, but more serious and even fatal cases have been described in France and around the world [6]. The emetic syndrome is characterised by vomiting and nausea, usually 30 minutes to 6 hours after ingestion, and can be confused with FBOs caused by Staphylococcus aureus. This syndrome is due to the ingestion of a thermostable toxin known as cereulide, pre-formed in food before ingestion of contaminated foods. The emetic $B$. cereus strains represent a cluster of strains characterised by the presence of the plasmid-located ces gene encoding an enzyme involved in cereulide synthesis [7].

Diarrhoeic symptoms are characterised by abdominal cramps and watery diarrhoea within 8 to 16 hours after ingestion of contaminated foods. These diarrhoeal symptoms and incubation periods can be easily confused with those caused by Clostridium perfringens food poisoning. More precise information about diarrhoeic strains is thus necessary to discriminate between possible causative agents and allow better diagnosis during FBOs. The diarrhoeal syndrome occurs after ingestion of vegetative cells or spores of diarrhoeic strains. This syndrome is generally attributed to at least three enterotoxins: haemolysin $\mathrm{BL}(\mathrm{Hbl})$, which has three components $B, L_{1}$ and $L_{2}$; non-haemolytic enterotoxin (Nhe) with its three components Nhe-A, Nhe-B and Nhe-C, and cytotoxin K (CytK). Two forms of cytotoxin K have been described, CytK-1 and CytK-2, the former being more cytotoxic than the latter [8]. In addition, $B$. cereus produces other toxins such as haemolysin II (Hlyll), metalloproteases such as InhA1 and InhA2, and the cell wall peptidase FM (CwpFM), which may also be involved in pathogenicity [9-11]. The pathogenic spectrum of $B$. cereus ranges from strains used as probiotics to strains that are lethal to humans and it remains difficult to predict the pathogenic potential of a strain. Apart from strains encoding ces or cytK-1 genes, which are virulent and well described in the literature $[8,12]$, the pathogenicity of $B$.cereus diarrhoeal strains is not fully understood and there are currently no specific markers to unambiguously differentiate between pathogenic and harmless strains. Indeed, the genetic studies carried out to date have been inconclusive and, regardless of the diseases they cause, all strains seem to carry genes encoding at least one of the known diarrhoeal toxins [13]. However, highly toxic strains do not necessarily overproduce these toxins [14]. The aim of this study was therefore to identify and characterise $B$. cereus strains from a unique national collection of 564 strains strongly related to 140 FBOs that occurred in France during 2007 to 2014 in order to improve the monitoring and investigation of $B$. cereusinduced FBOs, assess the risk of emerging clusters of strains and identify strain variability.

\section{Methods}

\section{Epidemiological data}

The epidemiological data related to each FBO were mainly collected through interviews or questionnaires by local health authorities. The suspected food in each FBO was traced by the local services of the French Ministry of Agriculture and Food (DDPP, Department for protection of populations). Collected data included a record of the type of suspected food, preparation location and date, type of packaging, number of human cases, symptoms and incubation periods. Then, a database of ANSES (French Agency for Food, Environmental and Occupational Health and Safety) was built, gathering epidemiological data as well as analytical results of $B$. cereus enumeration in food, strain characterisation and toxin production.

\section{Strain collection}

For each FBO, all bacterial strains from suspected food were isolated by plating leftovers on selective media plates allowing the discrimination of $B$. cereus from other bacterial pathogens ( $S$. aureus, C. perfringens, etc). Identification and numeration of one to five $B$. cereus strains per FBO were conducted by plating the strains on selective $B$. cereus agar media (MYP agar media: mannitol-phenol red-egg yolk medium (Biokar) according to the International Organization for Standardization (ISO) 7932 standard method or BACARA (BioMérieux), previously certified commercial 


\section{FIGURE 2}

Distribution of food-borne outbreaks by incubation periods for the entire Bacillus cereus collection, France, 2007-2014

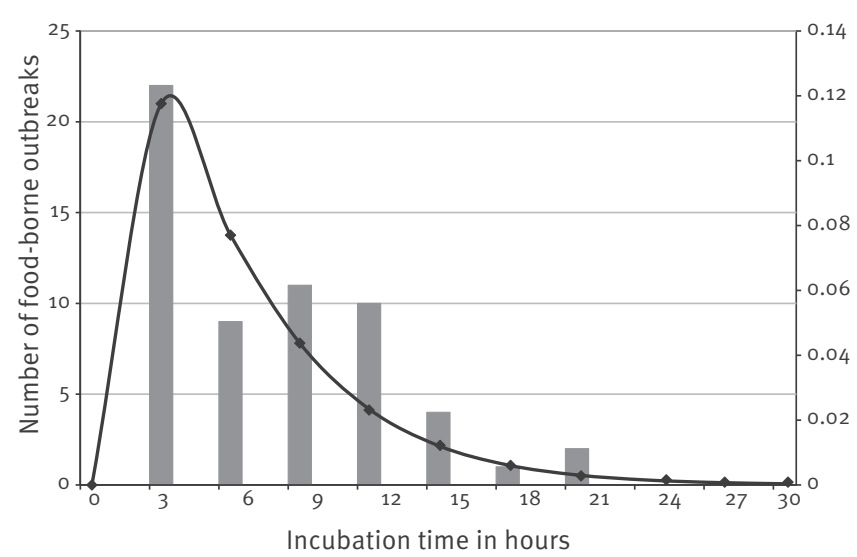

Bars represent the number of food-borne outbreaks for each incubation time.

alternative method (AES 10/10-07/10). All isolates were tested for haemolytic activity on sheep blood agar [15], lecithinase production on MYP agar media and starch hydrolysis on plate count agar (BioMérieux).

\section{DNA extraction}

DNA was extracted after overnight incubation of the strains at $30^{\circ} \mathrm{C}$ on trypticase soy agar with $0.6 \%$ yeast extract (Sigma-Aldrich) using the DNeasy Blood and Tissue Kit (Qiagen). DNA was quantified by absorbance at $260 \mathrm{~nm}$ on a Nanodrop1000 spectrophotometer (Thermo scientific).

\section{Coliphage M13 sequence-based PCR typing}

To study strain diversity and discriminate between strains isolated in samples within the same FBO, $B$. cereus strains were typed using coliphage $M_{13}$ sequence-based PCR (M13-PCR) derived from an RAPD technique and adapted from [16]. The PCR mix contained $40 \mathrm{ng}$ of DNA template, $0.9 \mathrm{mM}$ dNTP mix (Roche Diagnostics), $4 \mathrm{mM} \mathrm{MgCl} 2,2 \mu \mathrm{M}$ primer (GAGGGTGGCGGCTCT), $2.5 \mathrm{U}$ Goldstar DNA polymerase, and Goldstar buffer (Eurogentec). Thermal cycling using the Veriti Thermal Cycler (Applied Biosystems) included a denaturation step at $94^{\circ} \mathrm{C}$ for $3 \mathrm{~min}$, followed by 35 cycles of $1 \mathrm{~min}$ at $94^{\circ} \mathrm{C}, 1 \mathrm{~min}$ at $40^{\circ} \mathrm{C}, 8 \mathrm{~min}$ at $68^{\circ} \mathrm{C}$ and an elongation step at $68^{\circ} \mathrm{C}$ for $8 \mathrm{~min}$. The amplified DNA was analysed by SDS-PAGE electrophoresis. The M13-PCR patterns were visualised using ChemiDoc XRS imaging system. Then, DNA profiles were analysed with BioNumerics 7.1 software (Applied Maths).

\section{panC gene sequencing}

$B$. cereus strains were assigned to the seven known phylogenetic groups according to partial sequencing of the panC gene [17]. The sequencing was carried out by a commercial facility (Eurofins MWG Operon). The classification into the phylogenetic groups was performed using the algorithm described in [17]. The two typing methods panC gene sequencing and M13-PCR typing were used for separate objectives. This study did not explore the correlation between the two methods.

\section{Virulence gene detection}

The presence of potential virulence genes cytK-1, cytK2, hblA, hblc, hblD, nheA, nheB, nheC, hlyll and ces $[10,13]$ was evaluated by PCR. As the genetic diversity of $B$. cytotoxicus strains possessing cytK-1 is substantial, the primers used to detect the other virulence genes were not suitable for those particular strains. The PCR was performed with the Veriti Thermal Cycler. The final reaction mixture $(25 \mu \mathrm{L})$ contained $200 \mu \mathrm{M}$ dNTPs, $1 \mathrm{X}$ PCR buffer, 1 U FastStart Taq DNA Polymerase (Roche), 200-1,000 $\mathrm{nM}$ primers, and $2 \mu \mathrm{L}$ (ca $10 \mathrm{ng}$ ) template DNA. The amplification protocol comprised initial denaturation at $94^{\circ} \mathrm{C}$ for 5 min followed by 30 cycles of $94^{\circ} \mathrm{C}$ for $30 \mathrm{~S}, 58^{\circ} \mathrm{C}$ for $60 \mathrm{~s}$, and $72^{\circ} \mathrm{C}$ for $90 \mathrm{~S}$ and final extension at $72{ }^{\circ} \mathrm{C}$ for $7 \mathrm{~min}$. PCR products were analysed by SDS-PAGE electrophoresis.

\section{Enterotoxin quantification}

The production of the enterotoxins $\mathrm{Nhe}$ and $\mathrm{Hbl}$ was tested using two immunological tests, the BCET-RPLA Toxin detection kit (Oxoïd) and Tecra kit (BDE VIA, $3 \mathrm{M}$-Tecra), respectively, after culture in brain heart infusion broth (Biomérieux) for 6 hours at $30^{\circ} \mathrm{C}$ with stirring [18].

\section{Database and statistical analysis}

Strain characterisation results and epidemiological data were entered into a central database using BioNumerics software. The distribution of mean incubation periods, i.e. the time between ingesting contaminated food and symptom onset, was characterised using R 3.1 software and the 'fitdistrplus' package [19]. The log-normal was fitted to data according to maximum-likelihood estimation. To study seasonal variation in the occurrence of FBOs, the distribution of FBO dates was analysed throughout the year according to a previously described method [20].

\section{Results}

\section{Epidemiological and clinical data}

We studied a collection of $564 \mathrm{~B}$. cereus strains associated with $140 \mathrm{FBO}$ that occurred in France during 2007 to 2014. In 66 of the FBOs, B. cereus was isolated concomitantly with other bacterial species (including $S$. aureus and $C$. perfringens) during microbiological investigations, making it impossible to affirm that $B$. cereus was the cause of these FBOs. Our study therefore focused on $339 \mathrm{~B}$. cereus strains isolated from food samples analysed during $74 \mathrm{FBOs}$ where no other pathogenic bacteria were detected in the food during microbiological investigations (Table 1). These 74 FBOs resulted in 911 human cases. Data on sex and age of 


\section{FIGURE 3}

Coliphage M13 sequence-based PCR typing of selected Bacillus cereus strains isolated from various samples in two food-borne outbreaks, France, 2007-2014 (n = 11)

\section{A. M13-PCR patterns of Bacillus cereus strains isolated from $\mathrm{FBO}_{5}$}

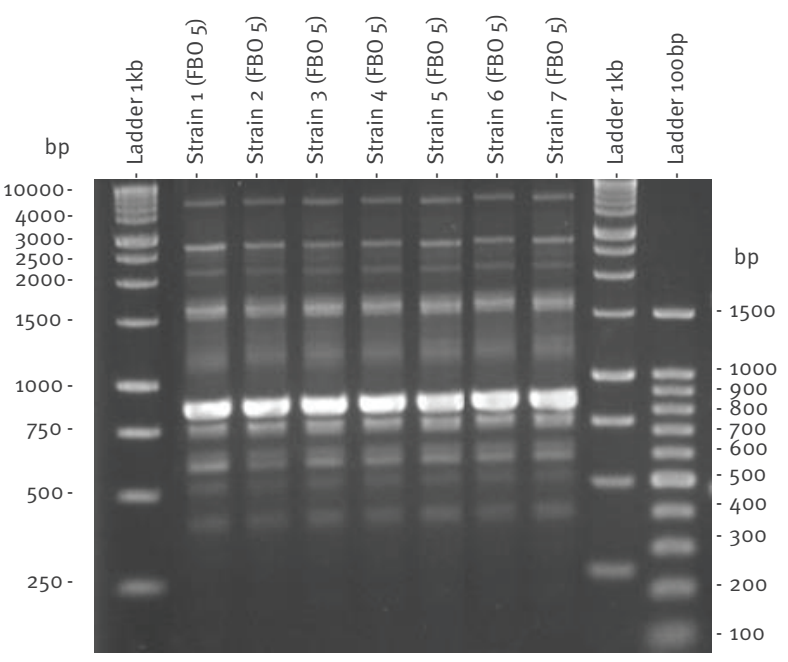

B. M13-PCR patterns of Bacillus cereus strains isolated from FBO 6

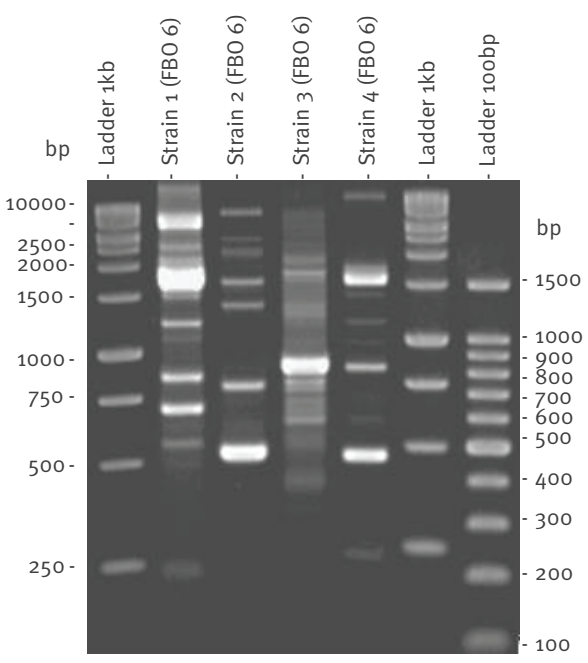

B: Bacillus; FBO: food-borne outbreak.

the cases were not always available and could therefore not be included in the study.

Over the eight years of the survey, the occurrence of FBOs was not subject to any seasonal effect (Figure 1). Emetic and diarrhoeal symptoms of human cases were often present at the same time and were reported for $57 \%$ of $\mathrm{FBOs}(42 / 74)$, whereas abdominal pains, diarrhoeic or emetic syndromes alone occurred in $4 \%$ (36/911), 12\% (109/911) and 13\% (118/911) total human cases, respectively.
Between 400 and $10^{8} B$. cereus CFU/g were found in the incriminated foods. Levels lower than $10^{5} \mathrm{CFU} / \mathrm{g}$ were observed in 48/57 FBOs due to diarrhoeal strains and in 11/17 FBOs due to emetic strains (Table 1). The incubation period (time between ingestion of contaminated food and symptom onset) varied from less than 3 hours to 21 hours (Figure 2). The mean incubation period was 5.7 hours (standard deviation (SD) 1.3) and could vary within the same FBO (Table 1). However, the incubation period was significantly shorter for emetic strains (carrying the ces gene) - mean: 2.6 hours (SD: 2.1 ) - compared with diarrhoeal strains (mean: 6.6 hours (SD: 1.4).

A single food source was incriminated for $57 \%$ of FBOs (42/74), of which $14 / 42$ were associated with starchy food, $8 / 42$ and 7/42 FBOs with vegetables and with mixed dishes composed of starchy food or vegetables, respectively (Table 1$)$. Only $14 \%(10 / 74)$ of FBOs were associated with foodstuffs of animal origin.

Furthermore, $60 \%$ of FBOs (44/74) occurred in institutional catering, involving $82 \%$ (747/911) of the human cases. FBOs were poorly reported in a family context, which represented $13 \%$ of the FBOs (10/74) and $7 \%$ $(64 / 911)$ of the human cases (Table 1$)$. The remaining $27 \%(20 / 74)$ of FBOs occurred in a commercial catering context, involving $11 \%(100 / 911)$ of cases.

\section{Strain characterisation}

Phenotypic analysis of the strains showed that $92 \%(312 / 339)$ of the strains produced lecithinase. Haemolytic activity on sheep blood agar was detected for $87 \%(295 / 339)$. Some $48 \%(163 / 339)$ of strains were able to hydrolyse starch (data not shown). The pan $C$ gene sequences were used to assign $B$. cereus strains to one of the seven previously described phylogenetic groups I to VII (Table 2). Group I was not represented in the strains analysed. Group III was the most represented $(46 \% ; 156 / 339)$. Groups IV and II represented $24 \%(81 / 339)$ and $19 \%(64 / 339)$, respectively. The distribution of strains in groups $\mathrm{VII}, \mathrm{VI}$ and $\mathrm{V}$ were 5\% (17/339), 4\% (14/339) and 2\% (7/339), respectively.

M13-PCR typing and genetic characterisation were conducted on all $339 \mathrm{~B}$. cereus isolates from the $74 \mathrm{FBOs}$ in order to discriminate different patterns and genetic profiles. Up to five isolates from each FBO were subjected to M13-PCR typing. For $42 \mathrm{FBOs}$, a unique $\mathrm{M}_{13}$ pattern was identified among all isolates recovered from samples within the same FBO (such as FBO number 5 , Figure $3 \mathrm{~A}$ ). In the remaining $32 \mathrm{FBOs}$, several M13 patterns were observed in samples within the same FBO (such as FBO number 6 with four different M13 patterns, Figure 3B). Thus, a total of 159 representative strains gathering 42 strains from the 42 FBOs of unique $M 13$ pattern and 117 strains representative of the $\mathrm{M} 13$ pattern diversity from the remaining $32 \mathrm{FBOs}$, were selected for further characterisation (Figure 4). 
FIGURE 4

Selection of food-borne outbreaks and panel of Bacillus cereus strains studied, France, 2007-2014 ( $=159)$

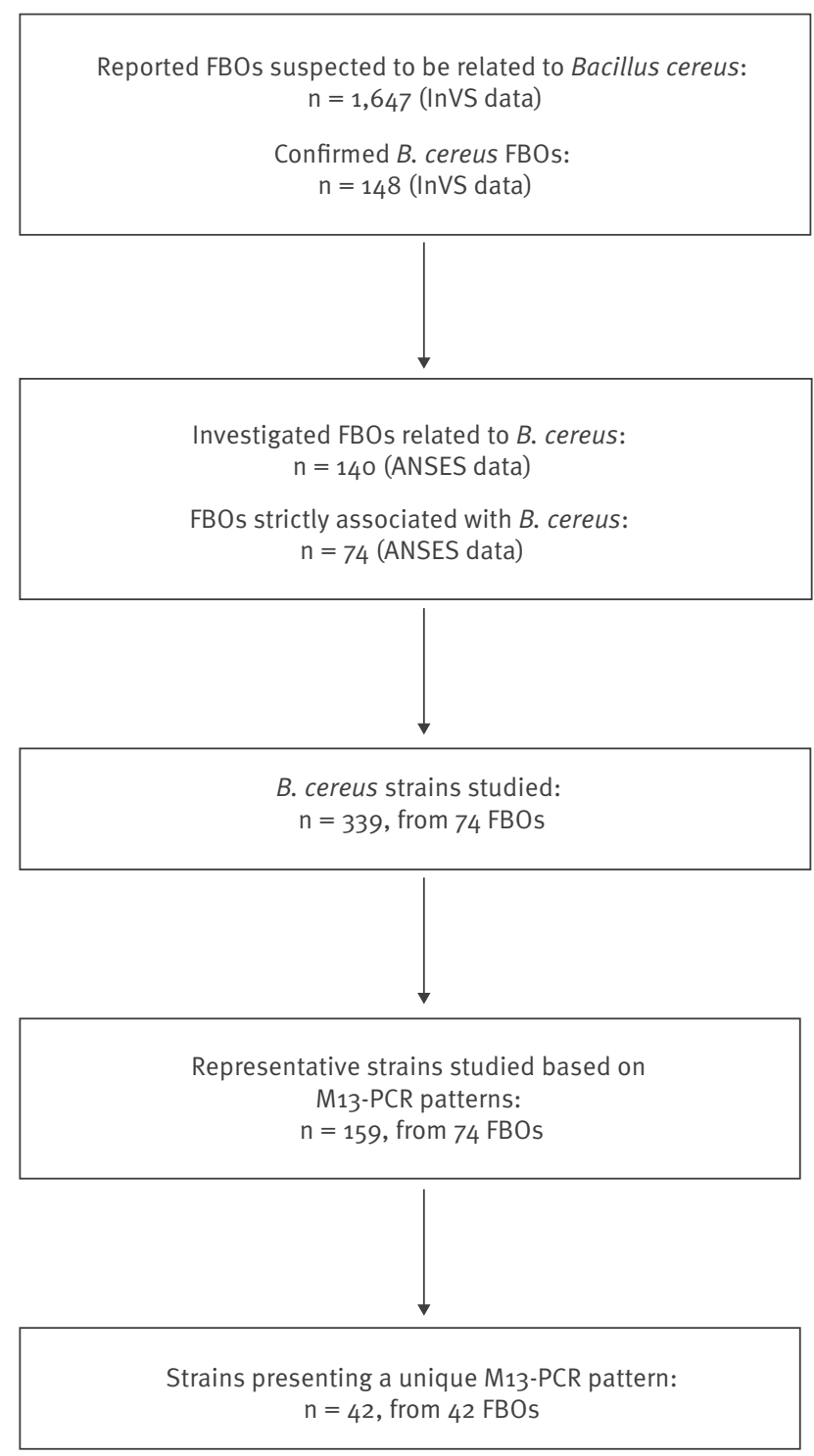

ANSES: French Agency for Food, Environmental and Occupational Health and Safety; FBO: food-borne outbreak; InVS: French Institute for Public Health surveillance, Santé publique France

The presence of major virulence genes was investigated (Table 2). The ces gene was detected in $16 \%$ $(25 / 159)$ of the $B$. cereus strains, meaning they were emetic strains. All the emetic strains belonged to phylogenic group III. The cytK-1 gene was detected in $5 \%$ (8/159) of strains, strictly associated with group VII and classified as $B$. cytotoxicus strains.

The most frequently distributed genes were those encoding enterotoxin Nhe, namely $n h e C$, nheB and nheA genes detected in respectively $100 \%$ (159/159), $99 \%(157 / 159)$ and $96 \%(153 / 159)$ of the tested strains.
The $h b l A, h b l D$ and $h b l C$ genes encoding enterotoxin $\mathrm{Hbl}$ were detected in 44\% (70/159), 44\% (70/159) and $40 \%(64 / 159)$ of the strains, respectively. The cytK-2 gene was detected in $42 \%(67 / 159)$ of strains and $23 \%$ (37/159) of strains carried hlyll.

These genetic features allowed to cluster the strains into 12 pathogenicity or 'genetic signatures' (GSs), GS1 to GS12 (Table 2). Some $84 \%(133 / 159)$ of the strains belonged to $\mathrm{GS}_{1}$ to $\mathrm{GS} 6$. The most frequent $\mathrm{GS}$ encountered in the collection was GS1, which accounted for $21 \%(34 / 159)$ of strains. In $\mathrm{GS} 1$, only Nhe-encoding genes were detected. The ces-positive strains were all placed in GS3 (except a single one in GS11) and possessed nhe genes in addition to the ces gene. GS11 also displayed the $c y t K-2$ gene. GS7 contained all the $B$. cytotoxicus strains carrying the $c y t K-1$ gene. GS8 was characterised by strains carrying $n h e B$ and $n h e C$ genes, and $h b l A$ and $h b l D$ genes. All the strains in this group belonged to phylogenetic group VI (Table 2). Several GSs defined in this study were associated with a single panC phylogenetic group, i.e. GS2 (IV), GS203 (III) GS7 (VII), GS8 (VI), GS11 (III) and GS12 (II).

\section{Discussion}

Food-borne infections are a common yet distressing and sometimes life-threatening problem for millions of people throughout the world [21]. B. cereus is reported to be the fourth major cause of notified FBOs in the European Union and the second in France $[4,5]$. However, B. cereus-associated outbreaks are likely to be underestimated, as they usually remain undiagnosed and therefore under-reported. If $B$. cereus is suspected, several identification tests can be performed: morphology tests on selective media, resistance to polymyxin B, lecithinase synthesis, haemolytic capacity, mannitol fermentation and starch hydrolysis [22]. These tests do not, however, reveal whether the isolated strains are pathogenic nor their genetic features.

The main strengths of our study are the unique national $B$. cereus strain collection linked to strong-evidence FBOs, the long period covered and an accurate epidemiological and strain characterisation. The study of symptoms does not readily allow the identification of the pathogen causing the FBO because gastroenteritis symptoms are also characteristic of other food-borne pathogens, especially S. aureus or C. perfringens [22]. However, phenotypic analysis and species discrimination allowed us to collect isolates and epidemiological data from 140 FBOs, of which 74 were strictly associated with $B$. cereus and affected 911 human cases. Considering food safety issues, this provides confirmation that $B$. cereus must be considered an important food-borne pathogen, and underlines the need to improve monitoring.

For 32 of these 74 FBOs, several strain patterns were distinguished from samples of a single FBO and it was not possible to discriminate which strain or which combination of strains was responsible for the outbreak, 
TABLE 1A

Epidemiological and microbiological data of food-borne outbreaks associated solely with Bacillus cereus, France, 2007-2014 (74 outbreaks, 339 strains)

\begin{tabular}{|c|c|c|c|c|c|c|c|c|c|}
\hline FBO & Year & Incriminated food & $\begin{array}{c}\text { Human } \\
\text { cases } \\
n\end{array}$ & $\begin{array}{c}\text { Incubation period } \\
\text { in hours }\end{array}$ & Symptoms & $\begin{array}{l}\text { Strain patterns } \\
\text { identified } \\
n\end{array}$ & $\begin{array}{l}\text { Outbreak } \\
\text { setting }^{\mathrm{a}}\end{array}$ & $\mathrm{CFU} / \mathrm{g}$ & $\begin{array}{l}\text { Genetic } \\
\text { signature }\end{array}$ \\
\hline 1 & 2007 & Semolina & 5 & $0-3$ & Vomiting & 1 & $\begin{array}{l}\text { Commercial } \\
\text { catering }\end{array}$ & $1.20 \mathrm{E}+07$ & $\mathrm{GS}_{3}$ \\
\hline 2 & 2007 & Shrimp & 12 & $21-24$ & $\begin{array}{l}\text { Vomiting, } \\
\text { diarrhoea }\end{array}$ & 1 & $\begin{array}{l}\text { Commercial } \\
\text { catering }\end{array}$ & $6.80 E+04$ & GS1 \\
\hline 3 & 2007 & Tomatoes & 4 & $0-3$ & $\begin{array}{l}\text { Vomiting, } \\
\text { diarrhoea }\end{array}$ & 1 & $\begin{array}{l}\text { Commercial } \\
\text { catering }\end{array}$ & $7.00 E+02$ & $\mathrm{GS}_{4}$ \\
\hline 4 & 2008 & Semolina & 40 & $12-15$ & Diarrhoea & 1 & Staff canteen & $1.20 E+03$ & $\mathrm{GS}_{1}$ \\
\hline 5 & 2008 & $\begin{array}{c}\text { Tabbouleh and minced } \\
\text { beef }\end{array}$ & NK & NK & NK & 1 & $\begin{array}{c}\text { Commercial } \\
\text { catering }\end{array}$ & $5.00 E+03$ & GS2 \\
\hline 6 & 2008 & $\begin{array}{l}\text { Mixed salad, goulash } \\
\text { mixed beef and mashed } \\
\text { potatoes }\end{array}$ & 19 & NK & $\begin{array}{l}\text { Vomiting, } \\
\text { diarrhoea }\end{array}$ & 4 & $\begin{array}{l}\text { Medico-social } \\
\text { institute }\end{array}$ & $6.00 E+02$ & $\begin{array}{l}\text { GS1; GS2; } \\
\text { GS7; GS12 }\end{array}$ \\
\hline 7 & 2008 & $\begin{array}{c}\text { Mashed potatoes and } \\
\text { boiled potatoes }\end{array}$ & 28 & NK & $\begin{array}{l}\text { Vomiting, } \\
\text { diarrhoea }\end{array}$ & 2 & $\begin{array}{l}\text { Medico-social } \\
\text { institute }\end{array}$ & $9.20 E+05$ & GS7; GS8 \\
\hline 8 & 2008 & $\begin{array}{l}\text { Mixed salad (rice and } \\
\text { corn) }\end{array}$ & 2 & NK & $\begin{array}{l}\text { Abdominal } \\
\text { pains, } \\
\text { vomiting }\end{array}$ & 1 & Staff canteen & $1.90 E+03$ & GS2 \\
\hline 9 & 2008 & Rice salad & 13 & $12-15$ & $\begin{array}{l}\text { Abdominal } \\
\text { pains, } \\
\text { vomiting, } \\
\text { other }\end{array}$ & 1 & $\begin{array}{l}\text { Medico-social } \\
\text { institute }\end{array}$ & $2.00 E+03$ & GS2 \\
\hline 10 & 2008 & Semolina & 61 & $3-6$ & $\begin{array}{l}\text { Abdominal } \\
\text { pains, } \\
\text { vomiting }\end{array}$ & 1 & $\begin{array}{l}\text { School } \\
\text { canteen }\end{array}$ & $1.00 E+04$ & $\mathrm{GS}_{7}$ \\
\hline 11 & 2008 & Semolina and lamb & 4 & $0-3$ & Vomiting & 1 & $\begin{array}{l}\text { Commercial } \\
\text { catering }\end{array}$ & $5 \cdot 50 E+04$ & $\mathrm{GS}_{3}$ \\
\hline 12 & 2008 & $\begin{array}{l}\text { Mashed potatoes, } \\
\text { mashed celery, roast } \\
\text { pork, sauce and pasta }\end{array}$ & 5 & $6-9$ & Diarrhoea & 2 & $\begin{array}{l}\text { Medico-social } \\
\text { institute }\end{array}$ & $1.50 E+05$ & $\mathrm{GS}_{4} ; \mathrm{GS}_{7}$ \\
\hline 13 & 2008 & $\begin{array}{l}\text { Cream caramel and } \\
\text { smoked salmon }\end{array}$ & 11 & $9-12$ & $\begin{array}{l}\text { Diarrhoea, } \\
\text { other }\end{array}$ & 3 & $\begin{array}{l}\text { Commercial } \\
\text { catering }\end{array}$ & $3.00 E+03$ & GS2; GS8 \\
\hline 14 & 2008 & Fruit salad & 70 & NK & NK & 1 & Staff canteen & $6.30 E+03$ & $\mathrm{GS}_{3}$ \\
\hline 15 & 2008 & Tandoori chicken & 10 & $6-9$ & $\begin{array}{l}\text { Vomiting, } \\
\text { diarrhoea }\end{array}$ & 2 & $\begin{array}{l}\text { Commercial } \\
\text { catering }\end{array}$ & $4.60 E+03$ & GS6 \\
\hline 16 & 2008 & Wheat & 3 & $9-12$ & Diarrhoea & 3 & $\begin{array}{l}\text { Commercial } \\
\text { catering }\end{array}$ & $1.60 E+06$ & $\mathrm{GS}_{1} ; \mathrm{GS}_{4}$ \\
\hline 17 & 2009 & Tiramisu & 15 & $0-3$ & $\begin{array}{l}\text { Vomiting, } \\
\text { diarrhoea }\end{array}$ & 1 & $\begin{array}{l}\text { Company } \\
\text { canteen }\end{array}$ & $8.00 E+02$ & GS9 \\
\hline 18 & 2009 & Fish in coconut milk & 2 & $0-3$ & $\begin{array}{c}\text { Nausea, } \\
\text { other }\end{array}$ & 1 & $\begin{array}{l}\text { Commercial } \\
\text { catering }\end{array}$ & $1.10 E+04$ & GS1 \\
\hline 19 & 2009 & Mashed potatoes & 24 & NK & $\begin{array}{l}\text { Vomiting, } \\
\text { diarrhoea }\end{array}$ & 1 & $\begin{array}{l}\text { School } \\
\text { canteen }\end{array}$ & $4.00 E+02$ & $\mathrm{GS}_{7}$ \\
\hline 20 & 2009 & Cantonese rice & 2 & $0-3$ & $\begin{array}{c}\text { Vomiting, } \\
\text { other }\end{array}$ & 1 & Family & $1.60 E+05$ & $\mathrm{GS}_{3}$ \\
\hline 21 & 2009 & $\begin{array}{c}\text { Mashed potatoes, roast } \\
\text { beef and French beans }\end{array}$ & 7 & $6-9$ & $\begin{array}{l}\text { Vomiting, } \\
\text { diarrhoea }\end{array}$ & 3 & $\begin{array}{l}\text { Medico-social } \\
\text { institute }\end{array}$ & $1.90 E+03$ & $\mathrm{GS}_{3} ; \mathrm{GS}_{5}$ \\
\hline 22 & 2009 & Quenelle of pike & 15 & $0-3$ & $\begin{array}{l}\text { Vomiting, } \\
\text { diarrhoea, } \\
\text { other }\end{array}$ & 1 & Staff canteen & $1.20 E+03$ & GS6 \\
\hline 23 & 2009 & $\begin{array}{l}\text { Sandwich (tomato, } \\
\text { carrots, chicken) }\end{array}$ & 7 & $0-3$ & $\begin{array}{l}\text { Abdominal } \\
\text { pains, } \\
\text { nausea }\end{array}$ & 4 & $\begin{array}{l}\text { Commercial } \\
\text { catering }\end{array}$ & $5.00 E+03$ & $\begin{array}{l}\text { GS1; GS2; } \\
\text { GS6; GS10 }\end{array}$ \\
\hline 24 & 2009 & Chicken sauce & 15 & NK & $\begin{array}{l}\text { Vomiting,- } \\
\text { diarrhoea }\end{array}$ & 1 & $\begin{array}{c}\text { Commercial } \\
\text { catering }\end{array}$ & $5.00 E+02$ & $\mathrm{GS}_{3}$ \\
\hline 25 & 2009 & Squid sauce & 3 & $9-12$ & Diarrhoea & 1 & Staff canteen & $2.10 E+05$ & $\mathrm{GS}_{12}$ \\
\hline 26 & 2009 & Sauteed shrimp & 4 & $0-3$ & $\begin{array}{l}\text { Vomiting, } \\
\text { diarrhoea }\end{array}$ & 7 & $\begin{array}{l}\text { Commercial } \\
\text { catering }\end{array}$ & $1.90 E+04$ & $\begin{array}{l}\mathrm{GS}_{1} ; \mathrm{GS}_{4} \\
\mathrm{GS} 6\end{array}$ \\
\hline 27 & 2009 & Semolina and peas & 7 & $3-6$ & $\begin{array}{l}\text { Nausea, } \\
\text { diarrhoea, } \\
\text { other }\end{array}$ & 5 & Staff canteen & $2.00 E+07$ & $\mathrm{GS}_{2} ; \mathrm{GS}_{5}$ \\
\hline 28 & 2010 & Salad & 44 & NK & $\begin{array}{l}\text { Vomiting, } \\
\text { diarrhoea, } \\
\text { other }\end{array}$ & 3 & $\begin{array}{l}\text { School } \\
\text { canteen }\end{array}$ & $1.00 E+03$ & GS2 \\
\hline
\end{tabular}

FBO: food-borne outbreak; NK: not known.

${ }^{a}$ Medico-social institutes included centres for disabled people, leisure centres, retirement homes and other community facilities. 
TABLE 1B

Epidemiological and microbiological data of food-borne outbreaks associated solely with Bacillus cereus, France, 2007-2014 (74 outbreaks, 339 strains)

\begin{tabular}{|c|c|c|c|c|c|c|c|c|c|}
\hline FBO & Year & Incriminated food & $\begin{array}{c}\text { Human } \\
\text { cases } \\
n\end{array}$ & $\begin{array}{c}\text { Incubation period } \\
\text { in hours }\end{array}$ & Symptoms & $\begin{array}{l}\text { Strain patterns } \\
\text { identified } \\
n\end{array}$ & $\begin{array}{l}\text { Outbreak } \\
\text { setting }^{\mathrm{a}}\end{array}$ & $\mathrm{CFU} / \mathrm{g}$ & $\begin{array}{l}\text { Genetic } \\
\text { signature }\end{array}$ \\
\hline 29 & 2010 & Pasta gratin & 2 & $0-3$ & $\begin{array}{c}\text { vomiting } \\
\text { - diarrhoea }\end{array}$ & 1 & Family & $1.50 \mathrm{E}+07$ & $\mathrm{GS}_{3}$ \\
\hline 30 & 2010 & Sausage and rice salad & 8 & $0-3$ & $\begin{array}{l}\text { Vomiting, } \\
\text { diarrhoea }\end{array}$ & 1 & Family & $3.00 E+03$ & $\mathrm{GS}_{3}$ \\
\hline 31 & 2010 & Paella & 27 & $6-9$ & Diarrhoea & 1 & $\begin{array}{l}\text { Medico-social } \\
\text { institute }\end{array}$ & $2.80 E+04$ & GS2 \\
\hline 32 & 2010 & $\begin{array}{c}\text { Samosa and marinated } \\
\text { shrimp tail }\end{array}$ & 3 & $0-3$ & Diarrhoea & 13 & $\begin{array}{l}\text { Commercial } \\
\text { catering }\end{array}$ & $2.90 E+05$ & $\begin{array}{l}\text { GS1; GS2; } \\
\text { GS4; GS5; } \\
\text { GS6; GS10 }\end{array}$ \\
\hline 33 & 2010 & Chicken & 8 & $3-6$ & $\begin{array}{l}\text { Vomiting, } \\
\text { diarrhoea }\end{array}$ & 1 & Family & $6,50 E+04$ & $\mathrm{GS}_{3}$ \\
\hline 34 & 2010 & Tabbouleh & 11 & NK & $\begin{array}{l}\text { Abdominal } \\
\text { pains, } \\
\text { other }\end{array}$ & 1 & $\begin{array}{l}\text { Medico-social } \\
\text { institute }\end{array}$ & NK & GS2 \\
\hline 35 & 2010 & $\begin{array}{l}\text { Mashed potatoes and } \\
\text { mashed vegetables }\end{array}$ & 19 & NK & $\begin{array}{c}\text { Vomiting, } \\
\text { diarrhoea, } \\
\text { other }\end{array}$ & 1 & $\begin{array}{l}\text { Medico-social } \\
\text { institute }\end{array}$ & $1.20 E+04$ & GS1 \\
\hline 36 & 2010 & $\begin{array}{l}\text { Pasta salad and rice } \\
\text { salad }\end{array}$ & 20 & $0-3$ & $\begin{array}{l}\text { Vomiting, } \\
\text { diarrhoea }\end{array}$ & 7 & Family & $9.60 E+07$ & $\begin{array}{l}\mathrm{GS}_{1} ; \mathrm{GS}_{3} \\
\mathrm{GS}_{4} ; \mathrm{GS}_{5} \\
\quad \mathrm{GS} 6\end{array}$ \\
\hline 37 & 2011 & $\begin{array}{c}\text { Mixed dish, soup, mixed } \\
\text { ham, mixed apple and } \\
\text { lasagne bolognese }\end{array}$ & 19 & $6-9$ & $\begin{array}{l}\text { Vomiting, } \\
\text { diarrhoea }\end{array}$ & 2 & $\begin{array}{l}\text { Medico-social } \\
\text { institute }\end{array}$ & $3.10 E+03$ & $\mathrm{GS}_{3}$ \\
\hline 38 & 2011 & Shrimp & 3 & $0-3$ & $\begin{array}{l}\text { Abdominal } \\
\text { pains, } \\
\text { vomiting, } \\
\text { other }\end{array}$ & 2 & $\begin{array}{l}\text { Commercial } \\
\text { catering }\end{array}$ & $1.90 E+03$ & GS1 \\
\hline 39 & 2011 & Moussaka & 1 & $3-6$ & $\begin{array}{l}\text { Abdominal } \\
\text { pains }\end{array}$ & 3 & $\begin{array}{c}\text { Commercial } \\
\text { catering }\end{array}$ & $8.20 E+04$ & $\begin{array}{l}\mathrm{GS}_{1} ; \mathrm{GS}_{4} \\
\quad \mathrm{GS}_{5}\end{array}$ \\
\hline 40 & 2011 & Spaghetti & 18 & $12-15$ & $\begin{array}{l}\text { Vomiting, } \\
\text { diarrhoea }\end{array}$ & 2 & $\begin{array}{c}\text { School } \\
\text { canteen }\end{array}$ & $1.00 E+03$ & GS8 \\
\hline 41 & 2011 & $\begin{array}{l}\text { Couscous, semolina, } \\
\text { lamb, vegetable dish }\end{array}$ & 19 & $9-12$ & $\begin{array}{c}\text { Nausea, } \\
\text { diarrhoea }\end{array}$ & 2 & $\begin{array}{l}\text { Medico-social } \\
\text { institute }\end{array}$ & $2.30 E+03$ & $\mathrm{GS}_{4} ; \mathrm{GS}_{11}$ \\
\hline 42 & 2011 & Carrots & 3 & $3-6$ & $\begin{array}{l}\text { Vomiting, } \\
\text { diarrhoea, } \\
\text { other }\end{array}$ & 1 & $\begin{array}{l}\text { Commercial } \\
\text { catering }\end{array}$ & $5.80 E+03$ & GS2 \\
\hline 43 & 2011 & Mashed potatoes & 10 & NK & $\begin{array}{l}\text { Vomiting, } \\
\text { diarrhoea }\end{array}$ & 1 & $\begin{array}{l}\text { School } \\
\text { canteen }\end{array}$ & $7.80 E+04$ & $\mathrm{GS}_{4}$ \\
\hline 44 & 2011 & Mashed celery & 15 & $12-15$ & $\begin{array}{l}\text { Vomiting, } \\
\text { diarrhoea }\end{array}$ & 1 & Staff canteen & $1.00 E+05$ & $\mathrm{GS}_{7}$ \\
\hline 45 & 2011 & Tomatoes and fish & 3 & $12-15$ & $\begin{array}{l}\text { Vomiting, } \\
\text { diarrhoea }\end{array}$ & 1 & $\begin{array}{l}\text { Medico-social } \\
\text { institute }\end{array}$ & $5.50 E+03$ & $\mathrm{GS}_{2}$ \\
\hline 46 & 2011 & Miso soup & 1 & NK & NK & 1 & Family & $1.50 \mathrm{E}+03$ & GS9 \\
\hline 47 & 2011 & Mixed salad & 3 & $0-3$ & $\begin{array}{l}\text { Vomiting, } \\
\text { diarrhoea }\end{array}$ & 1 & $\begin{array}{l}\text { Medico-social } \\
\text { institute }\end{array}$ & $2.00 E+03$ & $\mathrm{GS} 2$ \\
\hline 48 & 2011 & $\begin{array}{l}\text { Tomato, corn, courgette } \\
\text { dish }\end{array}$ & 9 & $6-9$ & $\begin{array}{l}\text { Abdominal } \\
\text { pains, } \\
\text { vomiting }\end{array}$ & 1 & $\begin{array}{l}\text { School } \\
\text { canteen }\end{array}$ & $4.00 E+03$ & $\mathrm{GS}_{2}$ \\
\hline 49 & 2011 & Samosa & 9 & $0-3$ & $\begin{array}{c}\text { Nausea, } \\
\text { other }\end{array}$ & 1 & $\begin{array}{c}\text { Commercial } \\
\text { catering }\end{array}$ & 1.,, $00 E+09$ & GS6 \\
\hline 50 & 2011 & $\begin{array}{l}\text { Rice and shellfish dish } \\
\text { and fish }\end{array}$ & 6 & $3-6$ & $\begin{array}{l}\text { Abdominal } \\
\text { pains, } \\
\text { nausea }\end{array}$ & 2 & Staff canteen & $2.70 E+03$ & $\mathrm{GS}_{5} ; \mathrm{GS} 6$ \\
\hline 51 & 2012 & $\begin{array}{l}\text { Apricot compote, } \\
\text { mashed carrots and } \\
\text { mashed broccoli }\end{array}$ & 8 & $9-12$ & Vomiting & 1 & $\begin{array}{l}\text { School } \\
\text { canteen }\end{array}$ & $7.00 E+02$ & $\mathrm{GS}_{1}$ \\
\hline 52 & 2012 & Paella & 2 & $0-3$ & $\begin{array}{l}\text { Vomiting, } \\
\text { diarrhoea, } \\
\text { other }\end{array}$ & 3 & $\begin{array}{l}\text { Commercial } \\
\text { catering }\end{array}$ & $2.10 E+04$ & $\begin{array}{l}\mathrm{GS}_{1} ; \mathrm{GS}_{3} \\
\quad \mathrm{GS} 10\end{array}$ \\
\hline 53 & 2012 & Pasta & 60 & $0-3$ & $\begin{array}{l}\text { Vomiting, } \\
\text { diarrhoea }\end{array}$ & 3 & $\begin{array}{l}\text { School } \\
\text { canteen }\end{array}$ & $5.80 E+04$ & $\mathrm{GS}_{5}$ \\
\hline 54 & 2012 & Mixed salad & 8 & $18-21$ & $\begin{array}{l}\text { Abdominal } \\
\text { pains, } \\
\text { vomiting, } \\
\text { other }\end{array}$ & 1 & Family & $4.00 E+02$ & $\mathrm{GS}_{2}$ \\
\hline
\end{tabular}

FBO: food-borne outbreak; NK: not known.

a Medico-social institutes included centres for disabled people, leisure centres, retirement homes and other community facilities. 
Epidemiological and microbiological data of food-borne outbreaks associated solely with Bacillus cereus, France, 2007-2014 (74 outbreaks, 339 strains)

\begin{tabular}{|c|c|c|c|c|c|c|c|c|c|}
\hline FBO & Year & Incriminated food & $\begin{array}{c}\text { Human } \\
\text { cases } \\
n\end{array}$ & $\begin{array}{c}\text { Incubation period } \\
\text { in hours }\end{array}$ & Symptoms & $\begin{array}{c}\text { Strain patterns } \\
\text { identified } \\
n\end{array}$ & $\begin{array}{l}\text { Outbreak } \\
\text { setting }^{\mathrm{a}}\end{array}$ & $\mathrm{CFU} / \mathrm{g}$ & $\begin{array}{l}\text { Genetic } \\
\text { signature }\end{array}$ \\
\hline 55 & 2012 & Chicken & NK & NK & Other & 3 & $\begin{array}{l}\text { Commercial } \\
\text { catering }\end{array}$ & $4.00 E+03$ & $\mathrm{GS}_{2} ; \mathrm{GS}_{5}$ \\
\hline 56 & 2012 & Lamb meat & 5 & $6-9$ & $\begin{array}{l}\text { Vomiting, } \\
\text { diarrhoea }\end{array}$ & 1 & Staff canteen & $2.30 \mathrm{E}+03$ & $\mathrm{GS}_{2}$ \\
\hline 57 & 2012 & Mashed fish & 18 & $9-12$ & $\begin{array}{l}\text { Vomiting, } \\
\text { diarrhoea }\end{array}$ & 1 & $\begin{array}{l}\text { Medico-social } \\
\text { institute }\end{array}$ & $4.00 E+02$ & $\mathrm{GS}_{7}$ \\
\hline 58 & 2012 & Diced mixed vegetables & 14 & $9-12$ & $\begin{array}{l}\text { Vomiting, } \\
\text { diarrhoea }\end{array}$ & 1 & $\begin{array}{l}\text { Medico-social } \\
\text { institute }\end{array}$ & $4.00 E+02$ & GS2 \\
\hline 59 & 2012 & Millefeuille pastry & 2 & $3-6$ & Nausea & 1 & $\begin{array}{c}\text { Commercial } \\
\text { catering }\end{array}$ & $2.00 E+03$ & GS2 \\
\hline 60 & 2012 & Onion soup & 5 & $9-12$ & Vomiting & 1 & $\begin{array}{l}\text { School } \\
\text { canteen }\end{array}$ & $4.00 E+02$ & GS2 \\
\hline 61 & 2013 & Semolina & 3 & $3-6$ & $\begin{array}{l}\text { Vomiting, } \\
\text { diarrhoea }\end{array}$ & 2 & Family & $1.00 E+04$ & $\mathrm{GS}_{5} ; \mathrm{GS}_{10}$ \\
\hline 62 & 2013 & Grilled pork & 2 & $6-9$ & $\begin{array}{l}\text { Vomiting, } \\
\text { diarrhoea }\end{array}$ & 2 & Family & $1.80 E+04$ & $\mathrm{GS}_{1} ; \mathrm{GS}_{9}$ \\
\hline 63 & 2013 & $\begin{array}{l}\text { Cheese-topped dish of } \\
\text { seafood, pasta }\end{array}$ & 15 & $6-9$ & $\begin{array}{l}\text { Diarrhoea, } \\
\text { other }\end{array}$ & 4 & Staff canteen & $6.50 E+03$ & $\begin{array}{l}\mathrm{GS}_{1} ; \mathrm{GS}_{3} \\
\mathrm{GS} 4\end{array}$ \\
\hline 64 & 2013 & Mashed potatoes & 12 & $3-6$ & $\begin{array}{l}\text { Vomiting, } \\
\text { diarrhoea, } \\
\text { other }\end{array}$ & 2 & $\begin{array}{l}\text { Medico-social } \\
\text { institute }\end{array}$ & $2.90 E+03$ & $\mathrm{GS}_{1} ; \mathrm{GS}_{3}$ \\
\hline 65 & 2013 & Pineapple & 5 & NK & Other & 2 & $\begin{array}{l}\text { School } \\
\text { canteen }\end{array}$ & $4.50 E+02$ & $\mathrm{GS}_{1} ; \mathrm{GS}_{9}$ \\
\hline 66 & 2013 & Mashed spinach & 13 & $6-9$ & $\begin{array}{l}\text { Vomiting, } \\
\text { diarrhoea }\end{array}$ & 3 & $\begin{array}{l}\text { Medico-social } \\
\text { institute }\end{array}$ & $1.00 E+04$ & $\mathrm{GS}_{1} ; \mathrm{GS}_{4}$ \\
\hline 67 & 2013 & Vegetable soup & 10 & $15-18$ & $\begin{array}{l}\text { Vomiting, } \\
\text { diarrhoea }\end{array}$ & 1 & $\begin{array}{l}\text { Medico-social } \\
\text { institute }\end{array}$ & $9,10 E+02$ & $\mathrm{GS}_{2}$ \\
\hline 68 & 2013 & Mixed salad & NK & $6-9$ & $\begin{array}{l}\text { Abdominal } \\
\text { pains }\end{array}$ & 1 & $\begin{array}{c}\text { School } \\
\text { canteen }\end{array}$ & $5.50 E+02$ & GS2 \\
\hline 69 & 2013 & Spinach & 8 & $0-3$ & $\begin{array}{c}\text { Vomiting, } \\
\text { diarrhoea, } \\
\text { other }\end{array}$ & 2 & Staff canteen & $3.60 E+02$ & $\mathrm{GS}_{5} ; \mathrm{GS}_{10}$ \\
\hline 70 & 2013 & Mixed pie & 19 & $12-15$ & $\begin{array}{l}\text { Vomiting, } \\
\text { diarrhoea }\end{array}$ & 1 & $\begin{array}{l}\text { Medico-social } \\
\text { institute }\end{array}$ & $4.00 E+02$ & $\mathrm{GS}_{1}$ \\
\hline 71 & 2014 & Mashed parsnips & 11 & $0-3$ & Vomiting & 2 & $\begin{array}{l}\text { School } \\
\text { canteen }\end{array}$ & $4,00 E+02$ & $\mathrm{GS}_{3}$ \\
\hline 72 & 2014 & Shrimp & 6 & $0-3$ & $\begin{array}{l}\text { Abdominal } \\
\text { pains, } \\
\text { vomiting }\end{array}$ & 2 & $\begin{array}{l}\text { School } \\
\text { canteen }\end{array}$ & $7.70 E+03$ & $\mathrm{GS}_{1}$ \\
\hline 73 & 2014 & Polenta & 25 & $18-21$ & $\begin{array}{l}\text { Abdominal } \\
\text { pains, } \\
\text { diarrhoea }\end{array}$ & 1 & $\begin{array}{l}\text { Medico-social } \\
\text { institute }\end{array}$ & $9.00 E+03$ & $\mathrm{GS}_{5}$ \\
\hline 74 & 2014 & $\begin{array}{l}\text { Semolina and ginger } \\
\text { (spice) }\end{array}$ & 11 & $0-3$ & $\begin{array}{l}\text { Vomiting, } \\
\text { diarrhoea }\end{array}$ & 2 & Family & $1.50 E+06$ & GS3; GS6 \\
\hline
\end{tabular}

FBO: food-borne outbreak; NK: not known.

a Medico-social institutes included centres for disabled people, leisure centres, retirement homes and other community facilities.

highlighting the need for accurate data on the diversity of the isolated strains during FBO investigation. In contrast, for 42 of the 74 FBOs, a unique strain pattern was identified for each FBO, providing a valuable strain collection for further analysis of the correlation between $B$. cereus genotypic features and associated diseases. Thus, the design of this study strengthens the interpretation of results and avoids bias regarding the bacterial agent causing the FBO.

Our study described 74 FBOs in which only $B$. cereus was recovered. Nevertheless, a limitation of our study is the exhaustivity of the studied FBOs during the period, as the French institute for public health surveillance (InVS, since 2016 Santé publique France) notified 148 FBOs between 2007 and 2014, in which B. cereus was the confirmed causative agent (Figure 4 ). The number FBOs notified to InVS was slightly higher than that of FBOs for which strains were received in ANSES and could be explained by the absence of microbiological investigation of such FBOs or the absence of isolation or sending $B$. cereus strains for further analysis.

Starchy food and vegetables were the most common food vehicles identified in our study. A previous study in commercial cooked chilled foods containing 
Genetic signatures of Bacillus cereus strains according to gene detection and panC phylogenetic groups, France, 2007-2014 $(\mathrm{n}=159)$

\begin{tabular}{|c|c|c|c|c|c|c|c|c|}
\hline \multirow{2}{*}{ Genetic signature } & \multirow{2}{*}{ Number of strains } & \multicolumn{6}{|c|}{ Genes detected } & \multirow{2}{*}{ panC phylogenetic groups } \\
\hline & & cytk-1 & cytk-2 & ces & hlyll & nheABC & $h b I C D A$ & \\
\hline GS1 & 34 & Neg & Neg & Neg & Neg & Pos & Neg & II -III - IV \\
\hline GS2 & 28 & Neg & Pos & Neg & Neg & Pos & Pos & IV \\
\hline GS3 & 25 & Neg & Neg & Pos & Neg & Pos & Neg & III \\
\hline GS4 & 18 & Neg & Pos & Neg & Neg & Pos & Neg & II - III \\
\hline GS5 & 18 & Neg & Neg & Neg & Pos & Pos & Pos & II - III \\
\hline GS6 & 10 & Neg & Pos & Neg & Pos & Pos & Pos & II - IV \\
\hline GS7 & 8 & Pos & ND & ND & ND & ND & ND & VII \\
\hline GS8 & 6 & Neg & Neg & Neg & Neg & $\mathrm{BC}$ & $A D$ & $\mathrm{VI}$ \\
\hline GS9 & 4 & Neg & Pos & $\mathrm{Neg}$ & Pos & Pos & Neg & II - III \\
\hline GS10 & 5 & Neg & Neg & $\mathrm{Neg}$ & Neg & Pos & Pos & IV - V \\
\hline GS11 & 1 & $\mathrm{Neg}$ & Pos & Pos & $\mathrm{Neg}$ & Pos & $\mathrm{Neg}$ & III \\
\hline GS12 & 2 & Neg & $\mathrm{Neg}$ & $\mathrm{Neg}$ & Pos & Pos & Neg & II \\
\hline
\end{tabular}

AD: only $h b l A$ and $h b l D$ detected; $B C$ : only $n h e B$ and $n h e C$ detected; ND: primers used are unable to detect these genes in GS7 group strains; Neg: negative; Pos: positive.

vegetables had shown high $B$. cereus contamination levels in raw vegetables [23]. Thus, particular attention should be taken during sampling and epidemiological investigation into potential $B$. cereus contamination of vegetables and starchy food. In our study, 60\% (44/74) of FBOs occurred in an institutional catering context. In the family context, $40 \%(26 / 64)$ of the cases were caused by emetic strains. Incorrect cooling of food during preparation or the conservation of cooked dishes at room temperature is thought to be the cause of cereulide production [24]. Moreover, the severity of symptoms associated with emetic strains might explain an increased reporting of these strains in the family context, compared with diarrhoeic strains which may remain undiagnosed and therefore under-reported.

Epidemiological and clinical data show that the type of symptom could not be specifically associated with the presence of emetic or diarrhoeic strains. Indeed, $57 \%(n=42)$ of the 74 FBOs shared both diarrhoeic and emetic syndromes although they were caused by only one type of strain. This may be partially explained by the fact that the emetic GS3 strains strongly produce Nhe enterotoxin (data not shown). We suspect that emetic strains may be ingested concomitantly with cereulide preformed in food, increasing pathogenicity and causing a mix of symptoms.

A significant difference was observed for the incubation period according to the type of strain. This is in accordance with previous findings showing that rapid onset of an emetic syndrome indicates intoxication by cereulide [25]. In contrast, ingestion of diarrhoeic bacteria can induce pathology via the production of enterotoxins in the small intestine, leading to a longer incubation period [26]. In some FBOs, the strains had short incubation periods ( $0-3$ hours) without involvement of emetic strains. We hypothesise that those strains might be responsible for rapid vomiting despite absence of the ces gene as previously described [27], or alternatively that the emetic toxin was concomitantly ingested with the contaminated food in addition to a ces-negative strain, or that unknown factors were responsible for vomiting symptoms.

Diarrhoeal diseases are often associated with $B$. cereus counts of $10^{5}$ to $10^{8}$ cells or spores [28]. In our study, concentrations below $10^{3} \mathrm{CFU} / \mathrm{g}$ were found in 12 of 57 foods related to diarrhoeal FBOs. This challenges the concept of a minimum infectious dose for $B$. cereus in diarrhoeal FBOs. A mathematical model based on systematic data collection of $B$. cereus concentrations in food implicated in outbreaks could be developed for dose-response assessment, in order to quantify infectivity associated with single cells [29]. Levels of at least $10^{5} \mathrm{CFU} / \mathrm{g}$ have generally been reported in the incriminated food linked to an emetic syndrome [30]. In our study, levels of as few as $400 \mathrm{CFU} / \mathrm{g}$ were implicated. This could be explained by cereulide's strong resistance to various treatments, underlining the importance of quantifying cereulide in foods. We cannot exclude the possibility that the CFUs recovered from leftover food accurately corresponded to the initial ingested CFUs. Indeed, food processing and storage before tests may have injured vegetative bacteria. However, we suspect that the spores, which are resistant to storage, are likely to be responsible for food-borne infections.

The genetic diversity of $B$. cereus strains involved in FBOs was revealed in our study by characterisation of strains based on the detection of the genes encoding cereulide, diarrhoeic toxins (Nhe, Hbl, CytK-1 and CytK2) and Haemolysin (Hlyll) and by phylogenetic classification. A total of 12 pathogenicity signatures based on 
genetic features of the strains were identified. Emetic strains were clustered in $\mathrm{GS}_{3}$, and possessed both the ces gene and the nhe genes. This corroborates with the M13 patterns, showing a high clonality of the GS3 group. Surprisingly, all the GS3 strains were unable to hydrolyse starch, although they were mostly found in starchy foods, as published elsewhere [31]. An atypical ces-positive strain was classified in $\mathrm{GS} 11$, characterised by the presence of the cytk-2 gene and the absence of Nhe production, despite detection of nhe genes (data not shown). This strain was detected once in the analysis of FBO 41, together with a strain belonging to GS4. Such atypical emetic strains have been described [25].

The diarrhoeic strains were more polymorphic than the emetic strains, displaying nine different genetic signatures, although six accounted for $84 \%(105 / 125)$ of the strains. Genes encoding Nhe were present in all GSs, but had variable Nhe production (data not shown), suggesting that other factors may be involved in pathogenicity. GS1 (nhe genes only) and GS2 ( $n h e, ~ h b l$ and cytK2) were the most prevalent GSs and may have a large impact on human health: they were present in $28 \%(20 / 74)$ and $31 \%(23 / 74)$ of FBOs, respectively. This is consistent with previous findings showing $28 \%$ and $24 \%$ of $B$. cereus strains belonging to $\mathrm{GS}_{1}$ and $\mathrm{GS}_{2}$, respectively [13]. Unlike $\mathrm{GS} 1$ strains, which were divided into three different phylogenetic groups, all GS2 strains belonged to phylogenetic group IV. These strains produce high concentrations of $\mathrm{Hbl}$, are strongly cytotoxic to Caco2 cells and are more prevalent among strains responsible for food poisoning [12]. These characteristics might partially explain the pathogenic potential of strains of GS2, although a synergistic effect of $\mathrm{Hbl}$ and Nhe on pathogenicity was not observed [32].

GS7 contained all the $B$. cytotoxicus strains carrying the cytK-1 gene, which were related to phylogenetic group VII. Strains carrying cytk-1 were mainly found in vegetable purees, corroborating results of a study showing that $35 \%$ of $B$. cereus strains found in commercial potato products taken on retail level or from catering establishments, possess cytk-1 [33].

Several studies suggest that the pathogenic potential of group VI strains is very low [12]. In our study, these GS8 strains were involved in two FBOs in association with other strains belonging to GS2 and GS7, (FBO 7 and 13 , respectively). Thus, it was not proven that GS8 strains were responsible for the symptoms. However, FBO 40, with 18 human cases, was caused by a unique GS8 strain, suggesting a virulence potential of this group [12].

Taken together, assignation of the strains according to genetic signature showed a high genetic diversity of $B$. cereus strains involved in FBOs and their pathogenic potential. Our results underline that $B$. cereus is a foodborne pathogen with a substantial impact on human health that should be investigated when a FBO is suspected. We propose an approach based on reported symptoms and incubation period. Particular attention should be given to vegetables and starchy food during the sampling as part of the investigation. We recommend collecting at least five colonies from each food sample potentially contaminated with $B$. cereus, with different morphologies, as several $B$. cereus with different genetic characteristics may be present in the same food product.

\section{Acknowledgements}

The authors would like to warmly thank all the district veterinary and food analysis laboratories for carrying out B. cereus detection and transmitting isolates together with epidemiological data to the Laboratory for Food Safety. We also address special thanks to Dr Marie Laure De Buyser, who initiated the strain collection and the Central Veterinary Services Laboratory Unit of the Laboratory for Food safety.

\section{Conflict of interest}

None declared.

\section{Authors' contributions}

BG participated in the design of the study and the draft of all the manuscript, he conducted the microbial analysis of confirmation and characterisation of the strains, as well collected the epidemiological data as part of a PhD work. SH participated in the design and coordination of the study, and the draft of all the manuscript. LG carried out the statistical analysis on the clinical and epidemiological data and took part in the draft of the manuscript. SCS took part in building of the strain collection and molecular characterisation. MLV and JG took part in the confirmation of isolates and PCR gene detection. SP was in charge of the enterotoxins production. VM and JAH participated in the design of the study and took part in the draft of the manuscript. NR participated in the design of the study, data interpretation and the draft of all the manuscript. $A B$ participated in the design and coordination of the study, and the draft of all the manuscript.

\section{References}

1. Guinebretière $M-H$, Auger $S$, Galleron N, Contzen $M$, De Sarrau $B$, De Buyser $M-L$, et al. Bacillus cytotoxicus sp. nov. is a novel thermotolerant species of the Bacillus cereus Group occasionally associated with food poisoning. Int J Syst Evol Microbiol. 2013;63(Pt 1):31-40. DOI: 10.1099/ijs.0.030627-0 PMID: 22328607

2. Drobniewski FA. Bacillus cereus and related species.Clin Microbiol Rev. 1993;6(4):324-38. DOI: 10.1128/CMR.6.4.324 PMID: 8269390

3. Mock M, Fouet A. Anthrax.Annu Rev Microbiol. 2001;55(1):64771. DOI: 10.1146/annurev.micro.55.1.647 PMID: 11544370

4. Santé publique France. Données relatives aux toxiinfections alimentaires collectives déclarées en France en 2013. [Data on collective food-borne outbreaks reported in France in 2013]. Saint-Maurice: Santé publique France. [Accessed Dec 2015]. French. Available from: http:// invs.santepubliquefrance.fr/Dossiers-thematiques/ Maladies-infectieuses/Risques-infectieux-d-originealimentaire/Toxi-infections-alimentaires-collectives/ Donnees-epidemiologiques

5. European Food Safety Authority, European Centre for Disease Prevention and Control (EFSA, ECDC). The European Union Summary Report on Trends and Sources of Zoonoses, Zoonotic Agents and Food-borne Outbreaks in 2013. EFSA Journal 2015;13(1):3991. doi:DOI: 10.2903/j.efsa.2015.3991,165 pp.

6. Dierick K, Van Coillie E, Swiecicka I, Meyfroidt G, Devlieger $H$, Meulemans A, et al. Fatal family outbreak of Bacillus 
cereus-associated food poisoning. J Clin Microbiol. 2005;43(8):4277-9. DOI: 10.1128/JCM.43.8.4277-4279.2005 PMID: 16082000

7. Ehling-Schulz M, Vukov N, Schulz A, Shaheen R, Andersson M, Märtlbauer E, et al. Identification and partial characterization of the nonribosomal peptide synthetase gene responsible for cereulide production in emetic Bacillus cereus. Appl Environ Microbiol. 2005;71(1):105-13. DOI: 10.1128/AEM.71.1.105 113.2005 PMID: 15640177

8. Fagerlund A, Ween O, Lund T, Hardy SP, Granum PE. Genetic and functional analysis of the cytK family of genes in Bacillus cereus.Microbiology. 2004;150(Pt 8):2689-97. DOI: 10.1099/ mic.0.26975-o PMID: 15289565

9. Ramarao N, Sanchis V. The pore-forming haemolysins of bacillus cereus: a review.Toxins (Basel). 2013;5(6):1119-39. DOI: 10.3390/toxins5061119 PMID: 23748204

10. Cadot C, Tran SL, Vignaud ML, De Buyser ML, Kolstø AB, Brisabois A, et al. InhA1, NprA, and Hlyll as candidates for markers to differentiate pathogenic from nonpathogenic Bacillus cereus strains. J Clin Microbiol. 2010;48(4):1358-65. DOI: 10.1128/JCM.02123-09 PMID: 20129969

11. Tran SL, Guillemet E, Gohar M, Lereclus D, Ramarao N. CwpFM (EntFM) is a Bacillus cereus potential cell wall peptidase implicated in adhesion, biofilm formation, and virulence.) Bacteriol. 2010;192(10):2638-42. DOI: 10.1128/JB.01315-09 PMID: 20233921

12. Guinebretière $M-H$, Velge $P$, Couvert $O$, Carlin $F$, Debuyser $M-L$, Nguyen-The C. Ability of Bacillus cereus group strains to cause food poisoning varies according to phylogenetic affiliation (groups I to VII) rather than species affiliation.J Clin Microbiol. 2010;48(9):3388-91. DOI: 10.1128/JCM.00921-10 PMID: 20660215

13. Yang IC, Shih DY-C, Huang T-P, Huang Y-P, Wang J-Y, Pan T-M. Establishment of a novel multiplex PCR assay and detection of toxigenic strains of the species in the Bacillus cereus group.) Food Prot. 2005;68(10):2123-30.PMID: 16245717

14. Jeßberger N, Krey VM, Rademacher C, Böhm M-E, Mohr A-K, Ehling-Schulz $M$, et al. From genome to toxicity: a combinatory approach highlights the complexity of enterotoxin production in Bacillus cereus. Front Microbiol. 2015;6:560. PMID: 26113843

15. Beecher DJ, Wong AC. Identification of hemolysin BL-producing Bacillus cereus isolates by a discontinuous hemolytic pattern in blood agar.Appl Environ Microbiol. 1994;60(5):1646-51. PMID: 8017944

16. Guinebretiere M-H, Nguyen-The C. Sources of Bacillus cereus contamination in a pasteurized zucchini purée processing line, differentiated by two PCR-based methods.FEMS Microbiol Ecol. 2003;43(2):207-15.PMID: 19719681

17. Guinebretière $M-H$, Thompson $F L$, Sorokin $A$, Normand $P$, Dawyndt $P$, Ehling-Schulz $M$, et al. Ecological diversification in the Bacillus cereus Group. Environ Microbiol. 2008;10(4):85165. DOI: $10.1111 / j .1462-2920.2007 .01495 . x$ PMID: 18036180

18. Guinebretière $M-H$, Broussolle $V$, Nguyen-The $C$. Enterotoxigenic profiles of food-poisoning and food-borne Bacillus cereus strains.J Clin Microbiol. 2002;40(8):3053-6. DOI: $10.1128 / J C M .40 .8 .3053-3056.2002$ PMID: 12149378

19. Pouillot R, Delignette-Muller ML. Evaluating variability and uncertainty separately in microbial quantitative risk assessment using two R packages.Int J Food Microbiol. 2010;142(3):330-40. DOI: 10.1016/j.ijfoodmicro.2010.07.011 PMID: 20674055

20. Guillier L, Thébault A, Gauchard F, Pommepuy M, Guignard A, Malle P. A risk-based sampling plan for monitoring of histamine in fish products.J Food Prot. 2011;74(2):302-10. DOI: 10.4315/0362-028X.JFP-10-234 PMID: 21333153

21. World Health Organization (WHO). WHO estimates of the global burden of foodborne diseases; foodborne disease burden epidemiology reference group 2007-2015. Geneva: WHO; 2015. Available from: http://apps.who.int/iris/ bitstream/10665/199350/1/9789241565165_eng.pdf

22. Cadel Six S, De Buyser M-L, Vignaud ML, Dao TT, Messio S, Pairaud S, et al. Toxi-infections alimentaires collectives à Bacillus cereus : bilan de la caractérisation des souches de 2006 à 2010. [Bacillus cereus food poisoning outbreaks: strain characterization results, 2006-2010]. Bull Epidemiol Hebd. 2012;(Hors-série):45-9. French. Available from: https://pro. anses.fr/bulletin-epidemiologique/Documents/BEP-mg-BE50art14.pdf

23. Choma $C$, Guinebretière $M H$, Carlin $F$, Schmitt $P$, Velge $P$, Granum PE, et al. Prevalence, characterization and growth of Bacillus cereus in commercial cooked chilled foods containing vegetables. J Appl Microbiol. 2000;88(4):617-25. DOI: 10.1046/j.1365-2672.2000.00998.x PMID: 10792519

24. Agata N, Ohta M, Yokoyama K. Production of Bacillus cereus emetic toxin (cereulide) in various foods.Int J Food Microbiol.
2002;73(1):23-7. DOI: 10.1016/S0168-1605(01)00692-4 PMID: 11883672

25. Ehling-Schulz M, Guinebretiere $M-H$, Monthán A, Berge 0 , Fricker M, Svensson B. Toxin gene profiling of enterotoxic and emetic Bacillus cereus.FEMS Microbiol Lett. 2006;260(2):232 40. DOI: 10.1111/j.1574-6968.2006.00320.x PMID: 16842349

26. Ceuppens S, Rajkovic A, Hamelink S, Van de Wiele T, Boon $\mathrm{N}$, Uyttendaele $\mathrm{M}$. Enterotoxin production by Bacillus cereus under gastrointestinal conditions and their immunological detection by commercially available kits.Foodborne Pathog Dis. 2012;9(12):1130-6. DOI: 10.1089/fpd.2012.1230 PMID: 23237409

27. Schmid D, Rademacher C, Kanitz EE, Frenzel E, Simons E, Allerberger $\mathrm{F}$, et al. Elucidation of enterotoxigenic Bacillus cereus outbreaks in Austria by complementary epidemiological and microbiological investigations, 2013. Int J Food Microbiol. 2016;232:80-6. DOI: 10.1016/j.ijfoodmicro.2016.05.011 PMID: 27257745

28. Granum PE, Lund T. Bacillus cereus and its food poisoning toxins.FEMS Microbiol Lett. 1997;157(2):223-8. DOI: 10.1111/ j.1574-6968.1997.tb12776.x PMID: 9435100

29. Teunis PFM, Kasuga F, Fazil A, Ogden ID, Rotariu O, Strachan NJC. Dose-response modeling of Salmonella using outbreak data.Int J Food Microbiol. 2010;144(2):243-9. DOI: 10.1016/j. ijfoodmicro.2010.09.026 PMID: 21036411

30. Gilber RJ, Kramer JM. Bacillus cereus food poisoning.). In: Cliver DC, Cochrane BA Editors. Progress in Food Safety. (proceeding of symposium) Madison (WI): Food Research Institute, University of Wisconsin-Madison, Madison; 1986. p. 85-93.

31. Chon JW, Kim JH, Lee SJ, Hyeon JY, Song KY, Park C, et al. Prevalence, phenotypic traits and molecular characterization of emetic toxin-producing Bacillus cereus strains isolated from human stools in Korea. J Appl Microbiol. 2012;112(5):1042-9. DOI: 10.1111/j.1365-2672.2012.05277.x PMID: 22394210

32. Sastalla I, Fattah R, Coppage N, Nandy P, Crown D, Pomerantsev AP, et al. The Bacillus cereus $\mathrm{Hbl}$ and Nhe tripartite enterotoxin components assemble sequentially on the surface of target cells and are not interchangeable. PLoS One. 2013;8(10):e76955. DOI: 10.1371/journal.pone.0076955 PMID: 24204713

33. Contzen M, Hailer M, Rau J. Isolation of Bacillus cytotoxicus from various commercial potato products.Int J Food Microbiol. 2014;174:19-22. DOI: 10.1016/j.ijfoodmicro.2013.12.024 PMID: 24440535

\section{License and copyright}

This is an open-access article distributed under the terms of the Creative Commons Attribution (CC BY 4.0) Licence. You may share and adapt the material, but must give appropriate credit to the source, provide a link to the licence, and indicate if changes were made.

This article is copyright of the authors, 2016. 